\title{
NEED ANALYSIS ON THE MATERIAL DEVELOPMENT OF TEACHING ESP SPEAKING
}

\author{
Fitria Lapele \\ State Islamic Institute of Ambon, Indonesia \\ fitrialapele@iainambon.ac.id
}

\begin{abstract}
University students must prepare themselves to be success in the global workforce. Hence, they should be able to speak English in the concerned fields of their specific major. In fact, speaking English for Specific Purpose (ESP) Students, especially students of non-English Language Education Department face some difficulties in constructing a good speaking. In this case, the ESP Speaking teacher should provide the good materials to help students master it easily. The teachers should consider using real life, authentic materials that reflect the target audience specialization. This study aimed to analyze the students' needs on material development of ESP Speaking at University of Muhammadiyah Malang. It was intended to know the types of needs analysis conducted by the teachers for developing the materials. That is why; a narrative design was used to gather the research data. Besides, the instruments were interview guide and teachers' documents. The result showed that: The teachers conducted four types of needs analysis for developing the materials, they are Target Situation Analysis, Wants, Means, and Subjective Needs Analysis, Present Situation Analysis, and Lack Analysis. All the types the teachers have done in knowing students' needs of ESP Speaking were generally in line with the requirements of good ways to develop ESP Speaking materials.
\end{abstract}

Keywords: ESP, Material Development, Need Analysis, Speaking

\section{A. INTRODUCTION}

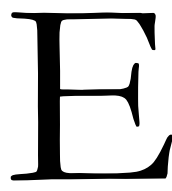
nglish for Specific Purpose (ESP) plays an important role in university. University students must prepare themselves to be successful members of the global workforce. Yoseto (2007) found that 46\% students of Mechanical Engineering Department said that materials for ESP course in their class were supporting materials for their future career. It can be said that the role of ESP for university students is totally important. Speaking for specific purposes in university level is very necessary for the students in the concerned fields of their major. In fact, to speak English is not easy because a speaker should be able to master the elements of speaking English such as grammar, vocabulary, pronunciation, intonation, fluency, body language, and gesture. Many of students by the end of their study period were still not able to speak English fluently (Poedjiastutie, 2017). Floriasti (2013) found that there were many errors done by the students when speaking. There were errors in the accuracy, pronunciation, spelling, stress, rhythm, intonation and grammar. These problems hindered them from having a fluency in speaking; thus, made them think that it was not easy to speak. I captured that still many students find the difficulties in learning English, especially speaking.

Teaching ESP is often described as a learner-based approach, which implies that one of the fundamental responsibilities of the ESP practitioner is to investigate the gap between learners' current 
and target competencies (Belcher, 2012). The diagnosis, referred to as needs analysis (NA), is a starting point for further activities and involves thorough research into the objective and subjective needs of the learner group and several other factors related to the planned ESP course, such as information about the environment in which it is to be run.

Needs analysis determines to design a language course. For example, Hamp-Lyons (2001) and Finney (2002) argue that a needs analysis has a vital role in the process of designing and carrying out any language course, whether it be English for Specific Purposes (ESP) or general English courses. Likewise, Mazdayasna \& Tahririan (2008) conducted a study with Iranian students from the faculty of nursing and midwifery. The results revealed that students needed to master the English proficiency because they needed to use not only Persian, but also English sources to study their subjects. It can be concluded that English is needed not only for English Language Education department students but also for all students in every major.

According to Sysoyev (2000), for many teachers, selection of teaching materials is based on their availability. Taking materials from available sources is not continually suggested. Sometimes it has limitation. Fauziah (2004) in her research focused on material in teaching speaking taken from Fun magazine found that the content of that magazine limited in the vocabulary and materials instructions.

In selecting materials, teachers must understand about the syllabus that will be used in the teaching and learning process. The criteria of syllabus must be considered carefully because the content in the syllabus will be used for materials in the teaching and learning process. The teachers may select materials from certain available sources if it matches with teaching and learning objectives. Emilianti (2013) found in her thesis about the use of internet sources for taking ESP materials that it had some advantages; firstly, it made students found authentic materials and, secondly, it could improve students' motivation in learning ESP. Based on this finding, the teachers are very suggested to find out more additional speaking material in internet source to enrich the available material.

Following that, such learning materials which are really suitable with the needs of the students are not always available. Marbuana (2007) found that the materials in "English for Mathematic 2" was not closely relevant to the students' needs because the content of this book did not provide all the students' need. Consequently, we cannot assure all material books fulfill students' needs. There are still some books that are not relevant with students' needs.

Abudhahir, et al. (2014) cite that materials development in ESP is very crucial. It should take into consideration what the learners' needs. Ideally, in developing the material, the teachers should follow some aspects. Firstly, the teachers know that principle. Tomlinson (2003) 
mentioned some for instance materials should achieve impact, materials should help learners to feel at ease, materials should help learners develop confidence, materials should require and facilitate learner self-investment, materials should expose the learners to language in authentic use, materials should provide the learners with opportunities to use the target, and so forth. Based on the preliminary study on some of ESP teacher (2015), the researcher found that they did not know well about the steps in developing the material. Still, there were some points that they followed, but not all. It may influence students' learning.

Another factor in developing materials is the level of authenticity of the material itself. The teachers should consider using real life, authentic materials that reflect the target audience specialization. This will help students who are weak in the English Language to at least speak for example due to the background knowledge that they have. By using real life materials, students will be happy and will feel at ease when they are learning because they are familiar and comfortable with the materials used in the classrooms.

Materials need to be balanced between language skills and content learning. Learners may be mostly interested in their surrounding reality and workplace. Practical matters that can be applicable to their working world need to be considered as the cornerstone to develop materials and alternative methods of evaluation. Thus, this study was intended to know the needs analysis conducted by the teachers for developing the materials in teaching ESP Speaking.

\section{B. REVIEW OF LITERATURE}

\section{Material for ESP Learning}

Material is an essential thing in ESP teaching. Tomlinson (2011) defines language learning materials as anything which is used by teachers or learners to facilitate the learning of a language. Materials include textbooks, workbooks, handouts, and even videos, CDs and DVDs. Tomlinson's (2011) definition of materials also includes newspapers, food packages, photographs, live talks by an invited native speaker and anything which is deliberately used to increase the learners' knowledge and/or experience of the language.

Tomlinson (2011) says that different types of learners need different types of materials. Materials have to follow principles, criteria, and procedures which match the distinctive features of the target learners and the environments they are learning in. For instance, an ESP course for airline engineers is going to have materials that are very different from the materials used for a business English course.

Along with course specialization, Barnard and Zemach (2003) highlight seven additional variables that impact the design and use of ESP materials. These include type of institution (e.g., 
company program or university), location (e.g., ESL or EFL context), classroom setting (e.g., conference room or classroom), technology (e.g., computers, internet access), learner qualities (e.g., proficiency level), make-up of class (e.g., similar/different proficiency levels), and teacher qualities (e.g., experience, fluency in students' L1).

Based on Barnard and Zemach's statement, the researcher may draw an understanding that those variables above should be measured as part of the needs assessment when developing, selecting, and using materials in ESP contexts. Most significantly, though, are the language structures and purposes that are distinctive to the specific language context.

\section{Need Analysis for Material Development}

The teaching of ESP is frequently described as a learner-based approach, which implies that one of the fundamental responsibilities of the ESP practitioner is to investigate the gap between learners' current and target competencies (Belcher, 2012). The investigation, referred to as needs analysis (NA), is a first spot for further activities and involves systematic research into the objective and subjective needs of the learner group and quite a lot of other factors related to the planned ESP course, such as information about the environment wherein it is to be run.

Needs analysis identifies a particular learner's or group of learners' communicative needs and their learning styles and preferences. It assists the teacher in identifying the learners' future target tasks and, if necessary, changing the syllabus, adapting it to the learners' specific needs, what learners know and what they need to learn in order to address these needs (Graves, 2001).

Likewise, Lowi (in Miyake and Tremarco; 2005) proposes types of needs analysis as follows:

1. Target Situation Analysis of learners: the tasks and activities in which English is used;

2. Wants, Means and Subjective Need Analysis: personal information about learners including factors that affect the way learners learn such as previous learning experiences, cultural information, reasons for learning ESP and its expectations;

3. Present Situation Analysis: Information about learners' current skills of language use;

4. Lack Analysis: the gap between Present Situation Analysis and Target Situation Analysis;

5. Learning Need Analysis: language learning information about the effective ways of learning the skills and language;

6. Linguistic Analysis, Discourse Analysis and Genre Analysis: professional communication information about knowledge of how language and skills are used in the target situation;

7. Means Analysis: information about the environment in which the course will be run. 
The method to collect needs analysis depends totally on the learners. They are submitted to interviews, observations, discussions, assessments, and questionnaires. Using questionnaires is considered the least consuming ways of collecting data (Hutchinson and Waters, 1996). Moreover, Jiajing (2007) explains that the use of questionnaires becomes one of the mainly common research methods since it enables the researchers to produce a large amount of information about many different issues such as communication difficulties, preferred learning styles, preferred classroom activities, attitudes and beliefs.

Conducting an ongoing NA is greatly recommended for students since the aim of an ESP program is to cope with the changing needs of the learners. Thus, an on going system of evaluation is important. It is purposed to present information on how the program can be improved through the introduction of changes that is deemed necessary (Ouakrime, 1997).

\section{METHOD}

Narrative research is designed to describe teachers' knowledge about what they know, how they think, how they develop professionally, and how they make decisions in the classroom (Creswell, 2012). This design is used in this study because it was intended to identify and explain the teachers' ways in conducting need analysis on material development in teaching ESP Speaking.

The participants of this present study were the teachers of ESP Speaking at UMM. Based on the problems and focus of the study, the subjects were selected by employing purposive sampling technique. It was done by taking the subjects based on certain purposes for getting the relevant data.

To collect the data the researcher applied some techniques and uses some instruments. The techniques included interview and documentation whereas the instruments were interview guide and documents.

Fraenkel (2012) defines that interview is an important way for a researcher to check the accuracy of the impressions that the researcher has gained through observation. The interviewee was the ESP Speaking teachers. According to Ary (2010), the most efficient way to collect the interview data is by using tape recorder. Therefore, in this study, the researcher used a tape recorder when conducting the interview to avoid misinformation. The interview was conducted to get the information related to the teachers' ways in conducting need analysis on material development.

Moreover, document analysis requires that data be examined and interpreted in order to elicit meaning, gain understanding, and develop empirical knowledge (Corbin \& Strauss, 2008; 
see also Rapley, 2007). Documents contain text (words) and images that have been recorded without a researcher's intervention.

In this present study, the documents such as syllabus, lesson plan, ESP Speaking books, and ESP teaching materials were reviewed and analyzed in an attempt to support the data that have already been collected from the interview. In this approach, the study made no attempts to isolate or manipulate the phenomena under investigation; insights and generalization emerged from close content with the data.

\section{The Steps of Data Collection}

The data collection was conducted to gather information about the teaching of ESP speaking at UMM. More specifically, the data were focused on the teachers' ways to conduct need analysis on the material material development. To collect the data, some steps were taken by the researcher as follows:

1. Interviewing the ESP Speaking teachers related to the types of need analysis they conducted to know students' needs.

2. Interviewing the ESP Speaking teachers related to the ways they conducted material selection and material development.

2. Reading the syllabus to get the information about basic competence, indicators, course description, course topics and assignments, and course policies and values.

3. Reading the teachers' lesson plan to get the details of the lesson, goals and objectives teaching materials, procedure of teaching, assignments, and evaluation of the lesson.

4. Reading the ESP speaking books as the source of material content.

5. Reading the ESP speaking materials to know their suitability with the students' needs and the teaching goals and objectives.

6. Identifying the teachers' ways in conducting the types of needs analysis on material development.

7. Choosing/selecting the teachers' ways in conducting needs analysis on material development.

\section{Data Analysis}

Hatch (2012) stated that data analysis is a systematic search for meaning. It is a way to process qualitative data that has been learned can be communicated to others. Analysis means organizing the data in ways that allow researchers to see patterns, identify themes, discover relationships, develop explanations, make interpretations, mount critiques, or generate theories. According to Ary (2010), data analysis is the most complex and mysterious phase of qualitative research. Data analysis in qualitative research is a time-consuming and difficult process because 
typically the researcher faces massive amount of field notes, interview transcripts, audio recording, video data, reflections, or information from documents, all of which must be examined and interpreted.

Analysis involves reducing and organizing the data, synthesizing, searching for significant patterns, and discovering what is important. The researcher must organize what he or she has seen, heard, and read and try to make sense of it in order to create explanations, develop theories, or pose new questions.

In analyzing the data, the researcher used the following procedures. Miles and Huberman (1984) state that data analysis as consisting of three concurrent flows of activity: data reduction, data display, and conclusion drawing/verification. Data reduction referred to selecting, focusing, simplifying, abstracting, transforming the data that appear in written-up field notes or transcriptions. The second major flow of analysis was data display. Generally, a display was an organized, compressed assembly of information that permits conclusion drawing and actions. The third stream of analysis activity was conclusion drawing and verification. From the start of data collection, the qualitative analyst was beginning to dedicate what things mean.

\section{FINDINGS AND DISCUSSION}

\section{Findings}

Based on the result of the data analysis, it was found that the ESP teachers at UMM conducted four types of needs analysis before developing the teaching materials. The needs analysis covered: (1) target situation analysis, (2) wants, means, and subjective needs analysis, (3) present situation analysis, and (4) lack analysis. Each explanation is presented as below.

\section{The teachers conducted target situation analysis.}

The result of the data analysis showed that the teachers conducted Target Situation Analysis (TSA) in order to know students' needs of learning ESP speaking. TSA relates to the tasks and activities in which English is used. It is shown in the data below.

Knowing the task and activity in which English is used is very important. By knowing that, I can capture what sort of English I should give to my students. To know that, I try to look for that information by interviewing the students and reading the books which are related to their major. By reading the books related to psychology, for example I know the topics linked to their major. Also, I match with their further profession, such as psychologist or counselor.

The teachers believed that to teach ESP speaking, it was necessary to know the needs of the students prior to the teaching and learning process. Therefore, they did a situation analysis to know their students' needs in learning ESP speaking. In this case, they interviewed the students and also read the related books focusing on the students' major. In this kind of needs 
analysis, the teachers tried to look for the information related to the tasks and activities that the students would do in their future profession.

The information related to the students' task for their future professions described the activities that the students did in the class. For instance, the teachers searched the information about tasks and activities for Psychology Department students. One of the professions that the psychology students may have is counselor. The task that the counselor should do is giving suggestion and solution for their clients. Here, the teachers looked for the information about the kind of activities that usually counselors do to give the suggestion and solution for their clients. In short, this kind of needs analysis helped the teachers answer the questions about the way how English is used, why it is used, when it is used, and to whom it is used.

From the students' answers, the teachers already received the information but it did not fulfill the whole information that they needed in order to create appropriate teaching materials. Hence, they did another way such as reading the books that were related to students' major. Even though the information they received was not too deep, it could guide them to know the students' needs in relation to the target situation of ESP speaking. It was enough to help them develop the appropriate materials for their ESP speaking students.

\section{The teachers conducted wants, means and subjective needs analysis.}

The result of data analysis showed that the teachers conducted Wants, Means, and Subjective (WMS) needs analysis in order to know the students' needs of learning ESP speaking. WMS analysis relates to personal information about learners, including the factors that affect the way the students learn ESP speaking such as previous learning experiences, reasons for learning ESP speaking and their expectations. It is shown in the data below.

I want to match the students' expectation with my materials. It is very nice when I teach them with the materials they like. I try to look at their previous experience in learning English, so I know their current English level. In the first meeting of the teaching learning process, I ask them about their reasons and expectations in learning ESP speaking. Also, I try to make a judgement about their characteristics by having a conversation with them. By knowing their characteristic, I can choose the suitable teaching strategy to them.

In conducting this kind of need analysis, the teachers tried to search the information connected to the students' personality. It linked with the students' experiences in learning English before, the reasons why the students learn English, and their expectations in learning English.

The information that the teachers received helped them measure students' English proficiency level from their learning experience. They found that the students varied in their English proficiency, even in one class. The variety of the students' English proficiency was used 
by the teachers as a consideration to develop the materials. In fact, the teachers' teaching experiences in regular and international classes showed students' different perception toward the material. In the regular class, some of highly proficient students perceived that this kind of material was too easy, whereas the other low proficient students told that it was difficult. Different with that, in the international class, the students mostly received the materials easy to be understood. The comparison above made the teachers really take into account about students' English proficiency and their learning experience to develop the materials.

Following that, the teachers also looked at the students' interest in learning ESP speaking. They directly asked the students related to their reasons and expectations. Most of the students answered just for making their speaking English fluent. Nevertheless, thing that made the teachers a bit confused was some students' admission about their little expectation in learning ESP speaking. Even they did not know what English would be used in their major. In this situation, the teachers tried to give the description about the importance of English for their future. In conclusion, from the variety of students' English learning experiences, reasons, and expectations in learning ESP speaking, the teachers could develop the materials appropriately.

\section{The teachers conducted present situation analysis.}

The result of the data analysis showed that the teachers conducted Present Situation Analysis (PSA) to know students' needs of learning ESP speaking. PSA relates to the information about students' current skills of language use. It is shown in the data below.

I concern on that point because it decides my material level. I have to create the material that match with my students' level. In this semester, I am teaching ESP speaking at regular and international classes. Both of these classes are different. I cannot match the class with high English proficiency and the low one. To know their present English ability, I look at their background of English learning. Moreover, I measure their ability after several meetings by considering their speaking performance. I mean, I always conduct the present situation analysis because their ability is not the same meeting by meeting.

PSA conducted by the teachers linked to the information about students' present speaking skill proficiency. It was because the teachers desired to develop the materials in the level of students' proficiency. They wanted to make the students easy in learning ESP speaking so that they could enjoy and understand the materials well.

The way teachers knew the students speaking English proficiency was by asking them to introduce themselves in first meeting of the class. It showed their fluency level of speaking and also their vocabulary mastery. Here, the teachers started to notice which students were in high level of speaking proficiency and which were in the lower level. Not only in the first meeting but also the teachers still conducted present situation analysis from the students' works in the following meetings. It helped them decide the materials level the teachers needed to develop. 
The result they received after conducting this PSA was that the students varied in their English proficiency. For instance, the proficiency of the international class was quite different from that of the regular class. The students in the international class had higher English proficiency compared with those in regular class. The result of this comparison made the teachers aware that they should not use the same materials for both classes. They adjusted the materials based on the students' level.

\section{The teachers conducted lack analysis.}

The research finding showed that the teachers conducted Lack Analysis (LA) in order to know the students' needs of learning ESP speaking. LA relates to the gap between PSA and TSA It is shown in the data below.

I have to know their weaknesses in speaking to help them reach the target of English use. In fact, the gap between students' present ability and the target ability is wide. I know it by comparing the result of present situation analysis and target situation analysis.

In this lack analysis, the teachers tried to analyze the gap between present situation analysis and target situation analysis. That gap helped them decide the aspects that should be put in the materials. They believed that to go to students' ideal speaking proficiency, they needed to fix the students' speaking problems in the present situation. By analyzing the gap, they developed the suitable materials to be taught to their students.

The gap found in this lack analysis was quite wide. It was a big matter for the low proficient students. They still felt strange in using English, even the vocabularies about their major were so unfamiliar to them. On the contrary, the gap was not a big matter for highly proficient students. They could follow the teachers' instruction in order to achieve the learning objectives. Both of the facts required the teachers to choose teaching materials accurately.

Considering that facts, the teachers matched the learning objectives and materials with the students' English proficiency. They did have the ambition to make the students achieve the ideal level of speaking English, but it did not mean that they gave all students high level materials. They noticed, at least, the students' confidence to speak English. Following that, they could use their speaking skill to look for overseas scholarship. In short, students' speaking skill could be useful for them in many ways.

\section{Discussion}

This study is concerned with the analysis of need analysis of the material development conducted by ESP Speaking teachers which cover some stages. Before the initiation of a new language material, vital preparatory work in the form of information gathering must take place. According to Belcher (2012), needs analysis is a first spot for further activities and involves 
systematic research into the objective and subjective needs of the learner group and quite a lot of other factors related to the planned ESP course, such as information about the environment wherein it is to be run.

Based on the findings, there are some types of needs analysis done by the teachers to conduct students' needs in learning ESP Speaking. The first is Target Situation Analysis (TSA). Miyake and Tremarco (2005) mention that TSA is the analysis of the tasks and activities in which English is used. It is correlated to the questions what, why, when, where, with whom, and how English is used. In other words, TSA is the analysis about the usage of English. The second is Wants, Means and Subjective (WMN) analysis. It is concerned with personal information about learners including the factors that affect the way learners learn such as previous learning experiences, cultural information, reasons for learning ESP and its expectations. The third is Present Situation Analysis (PSA). It tells about the information about learners' current skills of language use. The last is Lack Analysis (LA). It relates with the gap between PSA and TSA. Refer to the explanation from Miyake and Tremarco (2005), it can be concluded that the types of needs analysis teachers take to conduct students' needs analysis almost meet the ideal ways of conducting needs analysis. They conduct four of seven types of conducting students' needs analysis.

After knowing the students' needs in learning ESP speaking, the teachers select the materials. Dudley-Evans and St. John (2009) generally contend that the task of ESP teachers is providing good materials, not creating them. This implies suitable selection from the materials available on the market, their creative use, the adjustment of exercises and tasks to the needs of target learners as well as the supply of language input and additional exercises. Moreover, the materials collected at the NA stage can serve as authentic, needs-specific course materials and task stimuli (Hussin, 2002). In this study, the teachers take some steps of material selection by following the suggestion of Barnard and Zemach (2003). Firstly, the teachers determine the kind of language (English) the course will focus on. In order to select the appropriate ESP speaking material, the teachers choose the kind of language that is taught to the students. The information related to the materials selection is received from the result of needs analysis. Secondly, they determine the language skills to focus on. The teachers believe that the students need to master other language skill and component in order to speak English well. In this aspect, they select materials that are also related to listening skill and language components such as grammar and vocabulary. In the last stage of material selection, they determine the types of activities that will be used in the course based on the result of the needs analysis. They decide the activity to be applied for the students based on the students' characteristics and ability. 
Related to Barnard and Zemach's (2003) explanation about the steps to select the materials, it can be concluded that the way teachers select the materials in this research do not meet the qualification of good material selection, since there are still some steps that are not done by the teachers.

Following the material selection, the next point is the teachers' ways to develop the materials. Hyland (2006) argues that even though the materials development process can vary widely, depending on local circumstances, it typically begins with the identified need for materials. Borg and Gall (1983) propose the steps of developing materials. First of all, the teachers conduct need survey. The teachers have to pay attention to the students' needs that are used to reach the learning objective in the teaching activity. It is in line with the explanation of Tomlinson (2011) about conducting students' needs analysis. From the students' needs, the teacher constructs the lesson plan before implementing the materials and it can be used to avoid the unsuitable materials for the students. In line with this, Brown (2001) states that needs survey are important to ensure the material appropriate with the learners wants.

After getting the students' needs, the teachers start to develop the materials. Brown (2001) says that the material developers should be critical toward the materials prepared. They consider whether the materials serve the needs of the students or not. They developed the materials with several topics. The topics are referred to the standard competence and teaching objectives. Tomlinson (2011) also mentions that after getting the students' needs, the teacher decides the goals and objectives. To decide them, the teacher should consider the learners' level and wants.

\section{E. CONCLUSIONS}

Conducting students' needs analysis, the teachers used four types of need analysis. They conducted: (1) target situation analysis, (2) wants, means, and subjective needs analysis, (3) present situation analysis, and (4) lack analysis. The types that the teachers take to conduct students' need analysis are generally in line with the ideal types of conducting students' needs analysis, since they missed some essential types.

It is suggested for the teachers to conduct the complete types of needs analysis to know students' needs such as Learning Need Analysis, Linguistic, Discourse, and Genre Analysis, and Means Analysis. It is done in order to know the overall students' needs in learning ESP Speaking. Then, for developing the materials, the teachers should try out the material before it becomes a final material. Trying out the materials will help the teachers find out the weaknesses or limitation of the developed material. Later, it will be easier to be revised. 
Fitria Lapele, Need Analysis On The Material...

\section{REFERENCES}

Abudhahir, R. A., Mahdun, M., \& Nor, A. M. (2014). Needs analysis and material development in English for specific purposes in relation to English for islamic studies. E-proceedings of the Conference on Management and Muamalah (CoMM 2014).

Ary, D., Jacob, L. C., \& Razavieh, S. (2010). Introduction to Research in Education. Seventh Edition. USA: Wadsworth.

Barnard, R., \& Zemach, D. (2003). Materials for specific purposes. In B. Tomlison (ed.) Developing Materials for Language Teaching. London: Continuum.

Belcher, D.D. (2012). What ESP is and can be: An Introduction. In D.D. Belcher (ed.) English for Specific Purposes in Theory and Practice. Ann Arbor: University of Michigan Press.

Borg, W. R \& Gall, M. D. (2010). Educational Research. New York: Longman Inc.

Brown, D. H. (2001). Teaching by Principles: An interactive approach to language Pedagogy. Second Edition. New York: Longman.

Corbin, J. \& Strauss, A. (2008). Basic of Qualitative Research: Techniques and Procedures for Developing Grounded Theory. Third Edition. Thousand Oaks, CA: Sage.

Creswell, J. W. (2012). Educational Research: Planning, Conducting, and Evaluating Quantitative and Qualitative Research. Fourth Edition. USA: Pearson.

Dudley-Evans, T., \& St. John, M. J. (2009). Developments in English for Specific Purposes: A multidisciplinary approach. Cambridge: Cambridge University Press.

Emilianti. (2013). Internet Online Sources Used by the Teacher in ESP Writing Class at Faculty Teacher Training and Education of UMM. Unpublished Thesis. Malang: UMM.

Fauziah, U. (2004). The Analysis of Vocabulary and Material Instruction Written in "Fun" Magazine for YL. Unpublish Thesis. Malang: UMM.

Finney, D. (2002). The ELT curriculum: A flexible model for a changing world. In J. C. Richard, \&Renandya, W.A. (Ed.), Methodology in language teaching: An anthology of current practice (pp. 69-79). Cambridge: Cambridge University Press.

Floriasti, T.W. (2013). Improving Speaking Skills through the Use of Integrated Listening and Speaking Material for Student Teachers Academic Year 2012/2013. Unpublished Thesis. Yogyakarta: Yogyakarta State University.

Fraenkel, J. R., Wallen, N. E., \& Hyun, H. H. (2012). How to Design and Evaluate Research in Education. Eighth Edition. New York: McGraw-Hill.

Graves, K. (2001). A Framework of Course Development Processes. In: Hall, D.R. and Hewings, A. (Ed). Innovation in English Language Teaching. London, Routledge 
Hamp-Lyons, L. (2001). English for academic purposes. In R. Carter, \&Nunan, D. (Ed.), The Cambridge guide to teaching English to speakers of other languages (pp. 126-130). Cambridge: Cambridge University Press.

Hussin, B. (2002). An ESP Program for Students of Nursing. In T. Orr (red.). English for Specific Purposes. Alexandria, VA: TESOL.

Hutchinson, T. \& Waters, A. (2010). English for specific purposes: A learning-centered approach. Cambridge: Cambridge University Press.

Hyland, K. (2006). English for Academic Purposes. An Advanced Resource Book. New York: Routledge.

Jiajing \& Gao. (2007). Designing an ESP Course for Chinese University Students of Business. Asian ESP Journal, 3 (1).

Mazdayasna \& Tahririan. (2008). Developing a Profile of the ESP Needs of Iranian Students: The Case of Students of Nursing and Midwifery. Journal of English for Academic Purposes 7. Iran: Elsevier.

Marbuana, W. E. (2007). A Content Analysis of the ESP Textbook. for Mathematic Department "english for Mathematic 2" Published by LC UMM Press in Terms of Students Need. Unpublished Thesis. Malang: UMM.

Miles, M. B. \& Huberman. A. M. (1984). Qualitative Data Analysis: A Source Book of New Methods. Beverly Hills. California: SEGA Publication, Inc.

Miyake, M., \& Tremarco, J. (2005). Needs analysis for nursing students utilizing questionnaires and interviews. Kawasaki Journal of Medical Welfare - Vol 11.

Ouakrime, M. (1997). Perceptions and Reality: Demystifying ESP. Proceedings of the XVII MATE. Eds. El Mostapha El Hadad and others.

Poedjiastutie, D., Warnanda, K. N., Saputro, T. H., \& Hima, A. N. (2018). An Interpretive Study of the Communication Needs of English Department Students at University of Muhammadiyah Malang. JINoP (Jurnal Inovasi Pembelajaran), 3(2), 588-598.

Rapley, T. (2007). Doing Conversation, Discourse and Document Analysis. London: Sage.

Sysoyev, P. V. (2000). Developing an English for Specific Purposes Course Using a Learner Centered Approach: A Russian Experience. The Internet TESL Journal, Vol. VI, No. 3.

Tomlinson, B. (2003). Developing Materials for Language Teaching. London: Continuum.

Tomlinson, B. (2011). Material Developmen in Language Teaching. Second Edition. Cambridge: Cambridge University Press.

Yoseto. (2007). Developing the Materials of Speaking Instruction for EYL Classroom from English "Fun" Magazine. Unpublished Thesis. Malang: UMM. 